\title{
O EFeito Repristinatório no Controle Difuso DE Constitucionalidade E A VedaÇão DE DECISÕES SURPRESA
}

\author{
Olavo Augusto Vianna Alves Ferreira* \\ Eduardo Alexandre Young Abrahão**
}

1 Introdução. 2 Ato inconstitucional e sanção. 3 Origem e conceito do efeito repristinatório. 4 Aplicação do efeito repristinatório. 5 Restrição à aplicação do efeito repristinatório. 6 Efeito repristinatório no controle difuso. 7 Proibição legal de o magistrado proferir decisões inovando sem prévio contraditório. 8 Conclusões. Referências.

\begin{abstract}
RESUMO
O ato normativo inconstitucional é nulo. Quando é declarada a inconstitucionalidade de um ato normativo, os atos revogados por aquele serão automaticamente restabelecidos, já que não revogados validamente. Esta é a essência do chamado efeito repristinatório, que não se confunde, apesar da similitude semântica, com a repristinação. O efeito repristinatório será aplicado de forma automática na declaração de inconstitucionalidade de ato normativo. Ocorre no controle de constitucionalidade em geral; resta saber se, no controle difuso, deverá ser adotada a cautela de ser observado o contraditório a respeito, especialmente por força dos artigos $9^{\circ}$ e 10 do Código de Processo Civil atual.
\end{abstract}

Palavras-chave: Ato inconstitucional. Nulidade. Efeito repristinatório. Controle difuso e contraditório.

\section{INTRODUÇÃO}

Apesar de pouco usual, uma lei, ou mesmo um ato administrativo, pode restaurar outro já revogado, desde que o faça expressamente. A repristinação, ${ }^{1}$ nessa seara, não pode ser tácita, ${ }^{2}$ diante

* Doutor em Direito do Estado pela Pontifícia Universidade Católica de São Paulo (2008). Mestre em Direito do Estado Pontifícia Universidade Católica de São Paulo (2002). Procurador do Estado de São Paulo n. V. Foi membro eleito do Conselho Superior da Procuradoria Geral do Estado de São Paulo. Professor Titular do Programa de Mestrado em Direito e graduação da UNAERP. Foi Professor de direito constitucional do Curso LFG. Professor convidado de cursos de pós-graduação (PUC-COGEAE, UFBA, Escola Superior do Ministério Público, JUSPODIVM, FAAP e USP-FDRP), orientador da pós-graduação da Escola Superior da Procuradoria Geral do Estado de São Paulo e da pós-graduação de Processo Civil da USP-FDRP. Membro do Conselho Curador da Escola Superior da Procuradoria Geral do Estado de São Paulo. Autor de livros jurídicos. Avaliador de Cursos de Direito e IES: designado pelo Ministro da Educação Portaria n ${ }^{\circ} 1.137$, de 10 de setembro de 2010.E-mail: <olavoaferreira@hotmail.com>.

** Mestrando em Direito pela Unaerp, onde é Professor da Graduação. Foi advogado, Procurador do Estado e atualmente é Juiz de Direito. E-mail: <eabrahao@tjsp.jus.br>. 
da expressa previsão legal. ${ }^{3}$ Ela é típica do processo legislativo e também pode se fazer presente na edição de atos administrativos.

No controle concentrado de constitucionalidade, ocorre fenômeno às vezes confundido com a repristinação. Ao ser expurgado do ordenamento jurídico determinado texto ou trecho de texto legal ou de ato normativo, diante da sua nulidade, automaticamente os atos normativos anteriores são considerados não revogados validamente. Aqui, diversamente, não se trata de repristinação, mas de "efeito repristinatório" ${ }^{4}$ e, ao contrário da repristinação, esse efeito é sempre tácito ou automático.5-6

O Supremo Tribunal Federal, entretanto, no exercício do controle de constitucionalidade, pode decidir por afastar o efeito repristinatório, ${ }^{7}$ particularmente quando o efeito repristinatório possa gerar situação indesejada de restabelecer lei ou ato administrativo anterior inconstitucional, inclusive não impugnado na ação direta, ${ }^{8}$ como prevê o texto do $§ 2^{\circ}$ do art. 11 da Lei 9.868, de 10 de novembro de 1999. ${ }^{9}$

Consideramos o livro de Clèmerson Merlin Clève, ${ }^{10}$ cuja primeira edição surgiu em 1995, como marco teórico no Direito brasileiro sobre efeito repristinatório no controle abstrato. ${ }^{11}$

O efeito repristinatório, no controle abstrato, foi objeto de vários estudos, conforme ser verificará no desenvolvimento deste trabalho. Entretanto, resta sua apreciação no controle difuso, impondo-se a investigação se a aplicação do efeito repristinatório deverá observar a previsão do art. 10 do Código de Processo Civil de 2015, ${ }^{12}$ a qual proibiu que sejam proferidas decisões sobre temas não submetidos previamente ao contraditório, ainda que a matéria, como há hipótese em estudo, seja de ordem pública (artigos $9^{\circ 13}$ e $10^{14}$ ).

Trata-se da vedação das "decisões-surpresa"15, versando este estudo sobre a sua aplicação, quando há declaração de inconstitucionalidade no controle difuso.

Optamos pela divisão do desenvolvimento do trabalho em sete partes: trataremos do ato inconstitucional e a respectiva sanção; a origem e o conceito do efeito repristinatório; a sua aplicação; a restrição à aplicação do efeito repristinatório; o efeito repristinatório no controle difuso e a proibição legal de o magistrado proferir decisões inovando sem prévio contraditório, externando as conclusões ao final.

O método dedutivo foi adotado, realizando a pesquisa bibliográfica, e consiste na análise crítica sobre a doutrina nacional e sobre precedentes do Supremo Tribunal Federal, visando a consolidar entendimento para o desenvolvimento da problemática exposta.

\section{ATO INCONSTITUCIONAL E SANÇÃO}

Algumas palavras são necessárias acerca da inconstitucionalidade e da sua respectiva sanção, antes de tratarmos do efeito repristinatório. A inconstitucionalidade, vício que:

Não se confunde, vale ressaltar, com a sanção de inconstitucionalidade, que é a consequência estabelecida pela Constituição para a sua violação: a 
providência prescrita pelo ordenamento para a sua restauração, a evolução do vício rumo à saúde constitucional. Caso essa evolução não se verifique espontaneamente ou dependa de intervenção coativa, far-se-á uso dos remédios constitucionais, ou seja, dos instrumentos de garantia compreendidos no chamado controle de constitucionalidade. ${ }^{16}$

Impende salientar que não há previsão expressa na Constituição da sanção cominada ao ato inconstitucional, o que caracteriza o princípio da nulidade ${ }^{17}$ como implícito, ${ }^{18}$ sendo extraído do controle difuso de constitucionalidade. ${ }^{19}$

Na doutrina, ${ }^{20}$ defende-se que a modalidade de controle de constitucionalidade adotada identifica a sanção:

O sistema de controle de constitucionalidade funciona como critério identificador da sanção de inconstitucionalidade acolhida pelo ordenamento. Assim, a sanção de nulidade exige a presença do controle via incidental, apresentando a decisão que constata a incidência da sanção aparência de uma retroatividade radical, por redundar na negativa de efeitos ab initio ao ato impugnado. Já a sanção de anulabilidade aparece necessariamente associada ao controle concentrado, em que se produzam decisões anulatórias com eficácia erga omnes e não retroativas ou com retroatividade limitada. ${ }^{21}$

Canotilho concorda com os ensinamentos acima: "No caso do judicial review o efeito típico é o da nulidade e não simples anulabilidade." ${ }^{22}$ E afirma: a sanção nulidade é típica do controle difuso. Convém lembrar que: "A sanção de nulidade é tida como a mais eficiente no que diz respeito à preservação da supremacia das normas constitucionais, por impedir o ingresso do ato legislativo no plano da eficácia desde o seu nascedouro (ab initio), automaticamente (pleno iure)."23

Acrescentamos que a Constituição Federal dispõe, em cinco oportunidades, ${ }^{24}$ que a inconstitucionalidade é reconhecida por decisão declaratória, e não podemos desprezar o termo empregado pelo Poder Constituinte Originário, já que não há palavras inúteis no texto da Lei Maior. ${ }^{25}$ Esse fundamento reforça a tese da nulidade do ato inconstitucional, considerando que, segundo a doutrina, as decisões declaratórias ${ }^{26}$ reconhecem atos nulos, ${ }^{27}$ não anuláveis. ${ }^{28}$

Assim, pertence à tradição jurídica brasileira ${ }^{29}$ a teoria da nulidade da lei inconstitucional, fundada no aforismo pelo qual "inconstitucional statute is not law at all."30

Firmou-se o dogma da nulidade da lei inconstitucional na doutrina e na jurisprudência do Supremo Tribunal Federal, ${ }^{31}$ conferindo-se à declaração de inconstitucionalidade eficácia ex tunc. Como consequência, impõe-se o desfazimento no tempo de todos os atos passíveis de retroação que tiverem ocorrido durante a vigência do ato inconstitucional.

Verificada a premissa inicial no sentido da existência da sanção nulidade no ordenamento pátrio, resta conceituar o objeto do nosso estudo. 


\section{ORIGEM E CONCEITO DO EFEITO REPRISTINATÓRIO}

O efeito repristinatório é admitido pelo Pretório Excelso, ${ }^{32}$ desde a Constituição anterior, ${ }^{33}$ como decorrência do princípio da nulidade do ato inconstitucional. ${ }^{34}$ No direito estrangeiro, verificamos a existência do efeito em testilha em Portugal ${ }^{35}$ (artigo 282.1 da Constituição Portuguesa) ${ }^{36}$ na Áustria (art. 140.6) ${ }^{37}$ e na Alemanha (art. 35, Lei da Corte Constitucional Federal) ${ }^{38}$

A norma declarada inconstitucional não foi apta para revogar validamente a lei anterior que tratava da mesma matéria, uma vez que nasceu nula; ${ }^{39}$ este é o efeito repristinatório. $\mathrm{Na}$ verdade, ocorre, na hipótese, uma pseudo-revogação. ${ }^{40} \mathrm{O}$ fenômeno depende da atuação do Poder Judiciário no exercício do controle de constitucionalidade ou mesmo de ofício pelo Chefe do Poder Executivo, como veremos adiante.

Na feliz síntese de Rui Medeiros: "A norma pretensamente revogada pela norma inconstitucional se mantém em vigor." ${ }^{11}$ Declarada a inconstitucionalidade da norma revogadora, constata-se que ocorreu uma mera pretensão da norma nula revogar outra norma. ${ }^{42}$

Vem a propósito afirmar que repristinação e efeito repristinatório são vocábulos inconfundíveis, ${ }^{43}$ pois "a termos diversos não se deve atribuir o mesmo conteúdo." ${ }^{44}$ Clèmerson Clève ${ }^{45}$ aponta as diferenças entre os institutos. $\mathrm{O}$ efeito repristinatório é "O fenômeno da reentrada em vigor da norma aparentemente revogada. Já a repristinação, instituto distinto, substanciaria a reentrada em vigor da norma efetivamente revogada em função da revogação (mas não anulação) da norma revogadora." "46

Esta somente é permitida caso exista previsão legislativa expressa, por vedação da Lei de Introdução às normas do Direito Brasileiro, artigo $2^{\circ}$, parágrafo $3^{\circ}$, outras vezes referido.

A repristinação é um fenômeno legislativo que versa sobre vigência. $O$ efeito repristinatório é uma decorrência da declaração de nulidade de um ato normativo que não revogou validamente outro, envolvendo duas leis ou atos normativos e uma decisão judicial ou ato normativo editado pelo Chefe do Poder Executivo.

Em síntese, na repristinação, temos um instituto que envolve a vigência de três atos normativos, todos válidos, ao passo que, no efeito repristinatório, temos duas leis, e a posterior não revogou validamente a anterior, diante da sua inconstitucionalidade.

Na doutrina ${ }^{47}$ há quem se manifeste contrariamente ao efeito repristinatório, afirmando que não se harmoniza com o princípio da segurança jurídica, pois a restauração de atos normativos já revogados traz inconvenientes que teriam sido corrigidos pelo novo texto e restaurá-los seria de todo indesejável. Essa conclusão não pode ser aceita.

A ausência de tal efeito provocaria um vazio normativo, obrigando a integração da lacuna. ${ }^{48} \mathrm{O}$ efeito repristinatório é compatível sim com o princípio da segurança jurídica, ${ }^{49}$ pois viabiliza a certeza da norma aplicável ${ }^{50}$ sobre determinado assunto. Ademais, não houve revogação válida. 
Não há risco de o Poder Judiciário atuar como legislador positivo nesta hipótese, pois o efeito repristinatório é decorrência automática ${ }^{51}$ da decisão declaratória de inconstitucionalidade. As normas aparentemente revogadas pela norma inconstitucional "já estão latentes no ordenamento jurídico, não sendo, portanto, criadas pelo órgão de controle da constitucionalidade. ${ }^{52}$

\section{APLICAÇÃO DO EFEITO REPRISTINATÓRIO}

A aplicação do efeito repristinatório é expressamente prevista no Direito positivo (Lei $\mathrm{n}^{\mathrm{o}}$ 9.868/99, art. $\left.11, \S 2^{\mathrm{O}}\right)^{53}$ quanto ao deferimento de medida cautelar em ADI ou ADC. Apesar da omissão daquele texto legal, a mesma regra é aplicável às decisões de mérito nas ações de controle abstrato, já que decorrente da nulidade do ato inconstitucional. ${ }^{54}$

Quanto às decisões de mérito proferidas na ação direta de inconstitucionalidade e na ação declaratória de constitucionalidade, ${ }^{55}$ não há dúvida da existência do efeito em estudo como regra. Resta saber: e a decisão prolatada na arguição de descumprimento de preceito fundamental?

Entendemos que apenas têm efeito repristinatório as decisões prolatadas neste último instrumento que reconheçam o descumprimento de preceito fundamental por parte de determinado ato normativo, uma vez que o efeito repristinatório é aplicável apenas aos atos normativos, e não a todo e qualquer ato do Poder Público.

O Supremo Tribunal Federal ${ }^{56} \mathrm{e}$ a doutrina ${ }^{57}$ entendem que o chefe do Poder Executivo pode descumprir a lei inconstitucional, com fundamento no princípio da constitucionalidade (que está acima da legalidade), no princípio da supremacia da Constituição e de diversas normas constitucionais, tais com as previstas nos artigos $23, \mathrm{I},{ }^{58} 85,{ }^{59}$ dentre outras. Uma vez afastada a norma inconstitucional pelo Executivo, é aplicável o efeito repristinatório?

A resposta é afirmativa, e aplicável o efeito em estudo diretamente pelo Poder Executivo pelos mesmos fundamentos que nos referimos quanto ao Poder Judiciário, ${ }^{60}$ considerando-se que o Executivo não tem opção válida, salvo aplicar a norma aparentemente revogada, afastando a norma inconstitucional. Uma ressalva merece ser feita: uma vez apreciada a questão em processo objetivo, seja em sede cautelar ${ }^{61}$, seja de mérito, a posição do Judiciário é obrigatória, ante a existência do efeito vinculante. Da mesma forma, caso exista súmula com efeito vinculante sobre o assunto, deverá ser respeitada, sob pena de cabimento de reclamação em ambas as situações.

\section{RESTRIÇÃO À APLICAÇÃO DO EFEITO REPRISTINATÓRIO}

Clèmerson Merlin Clève adverte para o fato de que nem sempre o efeito repristinatório é vantajoso. A norma que foi revogada pela norma declarada inconstitucional pode: 
Padecer de inconstitucionalidade ainda mais grave que a do ato nulificado. Previne-se o problema com o estudo apurado das eventuais consequências que a decisão judicial haverá de produzir. $\mathrm{O}$ estudo deve ser levado a termo por ocasião da propositura, pelos legitimados ativos, da ação direta de inconstitucionalidade. Detectada a manifestação de eventual eficácia repristinatória indesejada, cumpre requerer, igualmente, já na inicial da ação direta, a declaração de inconstitucionalidade, e, desde que possível, a do ato normativo ressuscitado. ${ }^{62}$

O Supremo Tribunal Federal aplicou o entendimento acima, conforme se percebe pelo trecho da ementa abaixo transcrita:

A questão do efeito repristinatório indesejado. Necessidade, em tal hipótese, de formulação de pedidos sucessivos de declaração de inconstitucionalidade tanto do diploma ab-rogatório quanto das normas por ele revogadas, desde que também eivadas do vício da ilegitimidade constitucional. Ausência de impugnação, no caso, do diploma legislativo cuja eficácia restaurar-se-ia em função do efeito repristinatório. Hipótese de incognoscibilidade da ação direta. Precedentes. Ação direta não conhecida. ${ }^{63}$

Na ação direta de inconstitucionalidade n. 3660-MS, cujo Relator é Ministro Gilmar Mendes, foi reiterada pelo Pretório Excelso a possibilidade de modulação do efeito em estudo. ${ }^{64}$

Daniel Sarmento manifesta-se favoravelmente à modulação do efeito repristinatório indesejável:

Entendemos que, da conjugação dos arts. 11, § 2º e 27 da Lei 9868, é possível inferir uma autorização para que o STF, mediante um juízo de ponderação, restrinja ou até mesmo afaste os efeitos repristinatórios das decisões no controle de constitucionalidade. Mas, sempre que a restrição à repristinação decorrer não de um juízo sobre a inconstitucionalidade da lei revogada, mas de uma avaliação política do STF, calcada em 'razões de segurança jurídica ou de excepcional interesse social', pensamos que o quorum de $2 / 3$, previsto no art. 27 da Lei 9.868, também deverá ser exigido. ${ }^{65}$

Em síntese, o efeito repristinatório não deve ser aplicado nas hipóteses em que a norma revogada pela declarada inconstitucional também é inválida. ${ }^{66}$ Aplicável à hipótese, o instituto da modulação ou restrição dos efeitos da decisão que declara a inconstitucionalidade. ${ }^{67}$

\section{EFEITO REPRISTINATÓRIO NO CONTROLE DIFUSO}

Feitas as considerações sobre aplicação do efeito repristinatório no controle concentrado abstrato, resta abordar sua aplicação no controle difuso. ${ }^{68}$

O efeito repristinatório, como dito, é decorrência do princípio da nulidade do ato inconstitucional ${ }^{69}{ }^{70}$, portanto, não há como afastar sua aplicação no controle difuso. 
Em Portugal, por exemplo, o efeito repristinatório é aplicável na fiscalização concreta de constitucionalidade. ${ }^{71}$

O Supremo Tribunal Federal pronunciou-se favoravelmente à aplicação do efeito repristinatório no controle difuso, com efeito apenas entre as partes, logicamente. ${ }^{72}$

Não há como adotar entendimento em sentido diverso, considerando-se que o efeito repristinatório, repita-se, constitui em decorrência automática ${ }^{73}$ da declaração da inconstitucionalidade, consoante vimos anteriormente, e as normas aparentemente revogadas pela norma inconstitucional "já estão latentes no ordenamento jurídico, não sendo, portanto, criadas pelo órgão de controle da constitucionalidade." ${ }^{74}$

É o caso de refletir se a Resolução do Senado, nos termos do artigo 52, X, da Constituição Federal, ao suspender os feitos da norma declarada inconstitucional pelo Supremo, acarreta efeito repristinatório da norma anterior, isto é, após a declaração de inconstitucionalidade, é editada resolução nos termos acima, e esta produz efeitos repristinatórios?

Entendemos que a resposta é afirmativa. Não deve prosperar o vácuo normativo, após a suspensão da eficácia, por Resolução, da lei declarada inconstitucional pelo Supremo Tribunal Federal. Todavia, como a resolução do Senado não declara a inconstitucionalidade do ato normativo, mas simplesmente suspende os efeitos, não há efeito retroativo erga omnes, restando ao interessado ingressar com ação própria para discutir os atos praticados sob a égide da lei inconstitucional, respeitadas a prescrição e decadência. O Supremo Tribunal Federal tem precedente sobre o assunto. ${ }^{75}$

Não há fundamento, expresso ou implícito, apto para afastar a aplicação do efeito repristinatório no controle difuso, considerando-se que decorre do princípio da nulidade do ato inconstitucional, caracterizando-se como consequência automática da decisão que declara a inconstitucionalidade.

\section{PROIBIÇÃO LEGAL DE O MAGISTRADO PROFERIR DECISÕES INO- VANDO SEM PRÉVIO CONTRADITÓRIO}

Os artigos $9^{\circ}$ e 10 do Código de Processo Civil de $2015^{76}$ trouxeram a expressa necessidade do debate de temas que sejam utilizados pelo magistrado como fundamentos de decidir. Trata-se da vedação de "decisões surpresa", tida como "incensurável", por Araken de Assis, ${ }^{77}$ valorizando o contraditório.

É comum o julgador notar, no curso do processo, a presença de tema de ordem pública que, por vezes, não é ventilado pelas partes ou pelo Ministério Público.

Classicamente, por força do disposto no art. 301, $\$ 4^{\mathrm{o} 78}$, ou do art. 219, §5 ${ }^{\mathrm{o} 9}$, do Código de Processo Civil de 1973, conheceria da situação ex officio e extinguiria o processo, ${ }^{80}$ mesmo sem qualquer debate a respeito. 
Em época recente, no ano de 2006, facultou-se ao juiz a possibilidade de conhecer de ofício a prescrição de direitos disponíveis, a partir da modificação do texto do art. $219, \S 5^{\circ}$, do Código de Processo Civil de 1973, pela Lei no 11.280, de 16 de fevereiro de 2006..$^{81-82}$ Inclusive, o Superior Tribunal de Justiça, nos autos do Recurso Especial n ${ }^{\circ} 1.100 .156 /$ $\mathrm{RJ},{ }^{83}$ julgado sob o rito dos repetitivos, dispensou a necessidade de ouvir a Fazenda Pública a respeito da ocorrência da prescrição anterior à propositura de ação por ela, ${ }^{84}$ apoiado naquele fundamento.

Aquela conclusão, tida como "pacificada", dificilmente se sustentará frente à letra expressa do art. 10 do Código de Processo Civil de 2015, que prevê, em homenagem ao contraditório, verdadeira obrigação ao magistrado, sob pena de nulidade, assim sintetizada: "O juiz não pode decidir, em grau algum de jurisdição, com base em fundamento a respeito do qual não se tenha dado às partes oportunidade de se manifestar, ainda que se trate de matéria sobre a qual deva decidir de ofício." ${ }^{\$ 5}$

Atualmente, deparando-se com a situação que não foi objeto de contraditório prévio para as partes ${ }^{86} \mathrm{O}$ magistrado é obrigado a trazê-la à discussão, dando ciência aos litigantes e ao Ministério Público de sua existência para que possam se manifestar a respeito. Atuar de ofício não era, menos ainda hoje, fundamento bastante para deixar de lado o contraditório. ${ }^{87}$

O magistrado, no exercício do controle difuso de constitucionalidade, tem a prerrogativa de conhecer de ofício a inconstitucionalidade de leis ou atos administrativos em geral. ${ }^{88}$ Como dito linhas acima, se tal acontecer, aplicará o texto do art. 10 do Código de Processo Civil de 2015 e submeterá o tema ao contraditório, conforme ressalta Araken de Assis: "É o que exige o processo justo e equilibrado." ${ }^{\prime 9}$

O problema, entretanto, pode emergir no efeito repristinatório presente no controle difuso. Aquele efeito é automático, acontece mesmo que não haja pronunciamento judicial expresso a respeito.

O fato de o efeito repristinatório ser automático não impede o julgador de se referir a ele. Aliás, melhor (rectius: necessário) que o faça, por causa do "sagrado" contraditório, evitando-se a nulidade da decisão proferida, por afronta ao art. 10 do Código de Processo Civil de 2015.

Prima facie, poder-se-ia supor que a omissão judicial ${ }^{90}$ (em reconhecê-lo diretamente) não seria classificada como "decisão", pois o efeito repristinatório não foi invocado como fundamento ou consequência do provimento. Portanto, de forma precipitada, poder-se-ia concluir não ser relevante a falta do contraditório.

É inegável, entretanto, o nexo de causalidade entre o efeito repristinatório e a decisão judicial. Aquele depende desta. Aqui, fatalmente, não houve contraditório por iniciativa do juiz, pois, em verdade, o efeito repristinatório passou despercebido por ele. 
A consequência é uma decisão judicial carente de fundamentação adequada que abre margem à discussão a respeito da violação da letra do art. 10 do Código de Processo Civil, afetando o princípio do contraditório.

\section{CONCLUSÕES}

O princípio da nulidade do ato inconstitucional é implícito, extraído do controle difuso de constitucionalidade e da natureza declaratória da decisão que reconhece a inconstitucionalidade.

O efeito repristinatório decorre do princípio da nulidade do ato inconstitucional.

No Direito estrangeiro, verificamos a existência desse efeito em Portugal (artigo 282.1 da Constituição Portuguesa), na Áustria (art. 140.6) e na Alemanha (art. 35 da Lei da Corte Constitucional Federal).

A norma declarada inconstitucional não foi apta para revogar validamente a lei anterior que tratava da mesma matéria, uma vez que nasceu nula.

Repristinação e efeito repristinatório são inconfundíveis. Naquela temos um instituto que envolve a vigência de três atos normativos, todos válidos, ao passo que neste temos duas leis ou atos normativos, e o posterior não revogou validamente a anterior, diante da sua inconstitucionalidade.

O efeito repristinatório é compatível com o princípio da segurança jurídica, já que a sua inexistência provocaria um vazio normativo, obrigando a integração da lacuna.

O efeito repristinatório não deve restaurar ato normativo anterior inconstitucional. Ao ser reconhecida a inconstitucionalidade de um texto, a restauração do anterior só se opera se ele não padecer do mesmo vício.

Aplica-se o efeito em estudo na declaração de inconstitucionalidade de ato normativo no controle concentrado e no controle difuso, pois se trata de consequência da nulidade do ato normativo revogador.

No controle difuso, dada sua natureza inter partes, é imprescindível que o efeito repristinatório aconteça depois de prévio contraditório, sob o risco de nulidade da decisão, por negativa de vigência do art. 10 do Código de Processo Civil em vigor. 


\section{REFERÊNCIAS}

ASSIS, Araken de. Processo civil brasileiro: parte geral: fundamentos e distribuição de conflitos. São Paulo: Revista dos Tribunais, 2015. v. 1. p. 275.

BARROSO, Luís Roberto Barroso. Interpretação e aplicação da Constituição. São Paulo: Saraiva, 1996.

BASTOS, Celso Ribeiro. Hermenêutica e interpretação constitucional. São Paulo: Celso Bastos Editor, 1997.

. Curso de direito constitucional. 21. ed. São Paulo: Saraiva, 2000.

. O incidente de inconstitucionalidade: matéria jurídica. Revista Jurídica

Virtual, Brasília, n. 27, ago. 2001. Disponível em: <http://www.planalto.gov.br/ccivil/03/ revista/Rev27/Revista27.htm>. Acesso em: 15 nov. 2016.

BERNARDES, Juliano Taveira. Arguição de Descumprimento de Preceito Fundamental. Revista Jurídica Virtual, Brasília, n. 8, jan. 2000. Disponível em: <http://www.planalto. gov.br/CCIVIL/revista/Rev08/arg/descump/Juliano.htm>. Acesso em: 15 nov. 2016.

BIENBOJM, Gustavo. A nova jurisdição constitucional brasileira: legitimidade democrática e instrumentos de realização. Rio de Janeiro: Renovar, 2001.

BUENO, Cássio Scarpinella. Novo código de processo civil anotado. São Paulo: Saraiva, 2015.

CANOTILHO, J. J. Gomes. Direito constitucional. 4. ed. Coimbra: Livraria Almedina, [19--].

. Manual de direito constitucional. 2. ed. Coimbra: Coimbra Editora, 1988.

; MOREIRA,Vital. Constituição da república portuguesa anotada. 3. ed. Coimbra: Coimbra Editora, 1993.

CARVALHO, Paulo de Barros. Curso de direito tributário. 9. ed. São Paulo: Saraiva, 1996.

CLÈVE, Clèmersom Merlin. A fiscalização abstrata da constitucionalidade no direito brasileiro. 2. ed. São Paulo: Revista dos Tribunais, 2000.

COOLEY, Thomas. Princípios gerais de direito constitucional dos Estados Unidos da América do Norte. 2. ed. São Paulo: Revista dos Tribunais, 1982.

DIDIER JUNIOR, Fredie et al. Curso de direito processual civil: teoria da prova, direito probatório, ações probatórias, decisão, precedente, coisa julgada e antecipação dos efeitos da tutela. 10. ed. Salvador: Juspodivm, 2015. v. 2.

ENGISCH, Karl. Introdução ao pensamento jurídico. 6. ed. Lisboa: Fundação Gulbenkian, 1995. 
FERRARI, Regina Maria Macedo Nery. Efeitos da declaração de inconstitucionalidade. 4. ed. São Paulo: Revista dos Tribunais, 1999.

FERREIRA, Olavo Augusto Vianna Alves. Controle de constitucionalidade e seus efeitos. 3. ed. Salvador: Juspodivm, 2016.

FIGUEIREDO, Marcelo. O controle de constitucionalidade: algumas notas e preocupações. In: TAVARES, André Ramos; ROTHENBURG, Walter Claudius. Aspectos atuais do controle de constitucionalidade no Brasil, recurso extraordinário e arguição de descumprimento de preceito fundamental. No prelo.

GARCIA, Maria. Arguição de descumprimento: direito do cidadão. Caderno de Direito Constitucional e Internacional, v. 8, n. 32, p. 99-106, jul./set. 2000.

GRAU, Eros Roberto. Sobre a produção legislativa e sobre a produção normativa do direito oficial: o chamado "efeito vinculante." Revista Trimestral de Direito Público, n. 16, p. 31-38, 1996.

GRIMBERG, Carl. História universal: o império das pirâmides. Tradução Jorge B. de Macedo. São Paulo: Azul, 1989. v. 2.

GRINOVER, Ada Pellegrini. Controle da constitucionalidade. Revista Forense, v. 94, n. 341, p. 3-12, 1998.

LIMA, Gérson Marques de. O Supremo Tribunal Federal na crise institucional brasileira. Fortaleza: ABC Editora, 2001.

MARINONI, Luiz Guilherme e outros. Novo curso de processo civil: tutela dos direitos mediante procedimento comum. São Paulo: Revista dos Tribunais, 2015. v. 2.

MARTINS, Ives Gandra da Silva. Eficácia das decisões do Supremo Tribunal Federal. Revista de Processo, v. 25, n. 97, p. 241-250, jan./mar. 2000.

; BASTOS, Celso Ribeiro. Comentários à Constituição do Brasil. São Paulo: Saraiva, 1997. v. 4.

Saraiva, 1994.

; MENDES, Gilmar Ferreira. Ação declaratória de constitucionalidade. São Paulo:

MAXIMILIANO, Carlos. Hermenêutica e aplicação do Direito. 7. ed. São Paulo: Livraria Freitas Bastos, 1961.

MEDEIROS, Rui. A decisão de inconstitucionalidade. Lisboa: Universidade Católica Editora, 1999.

MENDES, Gilmar Ferreira. Jurisdição constitucional. 2. ed. São Paulo: Saraiva, 1998.

. O efeito vinculante das decisões do Supremo Tribunal Federal nos processos de controleabstrato de normas. Revista Jurídica Virtual, Brasília, n. 4, ago. 1999. Disponível 
em: <http:/www.planalto.gov.br/ccivil/revista/rev04/efeitovinculante.htm>. Acesso em: 15 nov. 2016.

- Direitos fundamentais e controle de constitucionalidade: estudos de direito constitucional. 12. ed. São Paulo: Celso Bastos Editor, 1999.

- Anteprojeto de lei sobre processo e julgamento da ação direta de inconstituciona-

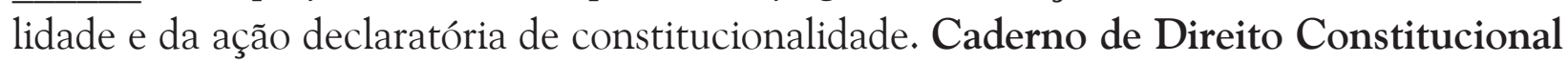
e Ciência Política, v. 7, n. 29, p. 24-36, out./dez. 1999.

1990.

. Controle de constitucionalidade: aspectos jurídicos e políticos. São Paulo: Saraiva,

- A ação declaratória de constitucionalidade: a inovação da emenda constitucional n. 3 de 1993. São Paulo: Saraiva, 1994.

- Arguição de descumprimento de preceito fundamental: demonstração da inexistência de outro meio eficaz. Revista Jus Navigandi, v. 5, n. 43, jul. 2000.

; MARTINS, Ives Gandra da Silva. Controle concentrado de constitucionalidade: comentários à Lei n. 9.868 de 10-11-1999. São Paulo: Saraiva, 2001.

MIRANDA, Jorge. Manual de direito constitucional. 2. ed. Coimbra: [s.n.], 1983.

. Teoria do estado e da constituição. Rio de Janeiro: Forense, 2002.

MOORE, Blaine Free. The Supreme Court and unconstitutional legislation. Studies in History, Economics and Public Law, v. 54, n. 2, 1913.

MORAIS, Carlos Blanco de. Justiça constitucional. Coimbra: Coimbra Editora, 2002. T. I. MUSCARI, Marco Antonio Botto. Súmula vinculante. São Paulo: Juarez de Oliveira, 1999. NERY JÚNIOR, Nelson; NERY, Rosa Maria Andrade. Código de processo civil comentado. 4. ed. São Paulo: Revista dos Tribunais, 1999.

. Comentários ao código de processo civil. São Paulo: Revista dos Tribunais, 2015.

NOBRE JÚNIOR, Edílson Pereira. O direito processual brasileiro e o efeito vinculante das decisões dos tribunais superiores. Revista dos Tribunais, São Paulo, v. 90, n. 785, p. 46-72, mar. 2001.

OTERO, Paulo. Ensaio sobre o caso julgado inconstitucional. Lisboa: Lex Edições Jurídicas, 1993.

PALU, Oswaldo Luiz. Controle de constitucionalidade: conceitos, sistemas e efeitos. 2. ed. São Paulo: Revista dos Tribunais, 2001.

PASSOS, José Joaquim Calmon de. Súmula vinculante. Revista Diálogo Jurídico, Salvador, n. 10, jan. 2002. Disponível em: < http://www.direitopublico.com.br > . Acesso em: 15 nov. 2016. 
PERTENCE, Sepúlveda. Informativo. Jornal Correio Braziliense, 20 nov. 2000. Disponível em: <http://www.agu.gov.br/Infordaagu/advgeral/artcbraz.doc> . Acesso em: 18 mar. 2002. POLLETI, Ronaldo. Controle da constitucionalidade das leis. Rio de Janeiro: Forense, 1985. RADBRUCH, Gustav. Introdução à filosofia do direito. Tradução Jacy de Souza Mendonça. Diponível em: <http://www.valorjustica.com.br/introducao.pdf>. Acesso em: 15 nov. 2016. RAMOS, Elival da Silva. A inconstitucionalidade das leis. São Paulo: Saraiva, 1994.

RAMOS, Saulo. Efeito vinculante de decisões dos Tribunais Superiores. Revista Brasileira de Ciências Criminais, São Paulo, v. 4, n. 13, 1996.

ROGIERO, Nuno. A lei fundamental da República Federal da Alemanha. Coimbra: Coimbra Editora, 1996.

SAMPAIO, José Adércio Leite. A constituição reinventada pela jurisdição constitucional. Belo Horizonte: Del Rey, 2002.

; CRUZ, Álvaro Ricardo de Souza. Hermenêutica e jurisdição constitucional. Belo Horizonte: Del Rey, 2001.

SARMENTO, Daniel. A eficácia temporal das decisões no controle de constitucionalidade, hermenêutica e jurisdição constitucional. Belo Horizonte: Del Rey, 2001.

SILVA, José Afonso da. Curso de direito constitucional positivo. 11. ed. São Paulo: Malheiros, 1996.

. Da jurisdição constitucional no Brasil e na América Latina. Revista da Procuradoria Geral do Estado de São Paulo, São Paulo, v. 13, n. 15, p. 105-171, 1978 .

. Proteção constitucional dos direitos humanos no Brasil: evolução histórica e direito atual. Revista da Procuradoria Geral do Estado de São Paulo, São Paulo, n. especial, p. 159-185, set. 1998.

SILVA, Vírgilio Afonso da. Interpretação constitucional e sincretismo metodológico. In: . Interpretação constitucional. São Paulo: Malheiros, 2005. p. 115-143.

SILVA, José de Anchieta da. A súmula do efeito vinculante amplo no direito brasileiro: um problema e não uma solução. Belo Horizonte: Del Rey, 1998.

SIQUEIRA JÚNIOR, Paulo Hamilton. Controle de constitucionalidade. São Paulo: Editora Juarez de Oliveira, 2001.

STRECK, Lenio Luiz. Jurisdição constitucional e hermenêutica: uma nova crítica do Direito. Porto Alegre: Livraria do Advogado, 2002.

. Súmulas no Direito brasileiro: eficácia, poder e função: a ilegitimidade constitucional do efeito vinculante. Porto Alegre: Livraria do Advogado, 1998. 
TAVARES, André Ramos. Tribunal e jurisdição constitucional. São Paulo: Celso Bastos Editor, 1998.

. Súmula de efeito vinculante. As tendências do direito público no limiar de um novo milênio. São Paulo: Saraiva, 2000.

; ROTHENBURG, Walter Claudius. Arguição de descumprimento de preceito constitucional fundamental: análises à luz da Lei n. 9882/99. São Paulo: Atlas, 2001.

. Tratado da arguição de preceito constitucional fundamental: (lei n. 9.868/99 e Lei n. 9882/99). São Paulo: Saraiva, 2001.

TEMER, Michel. Elementos de direito constitucional. 12. ed. São Paulo: Malheiros, 1996. THEODORO JÚNIOR, Humberto. Curso de direito processual civil. 18. ed. Rio de Janeiro: Forense, 1996.

VELOSO, Zeno. Controle jurisdicional de constitucionalidade. 2. ed. Belo Horizonte: Del Rey, 2000.

VELLOSO, Caio Mário da Silva. Do poder judiciário: como torná-lo mais ágil e dinâmico Efeito vinculante e outros temas. Cadernos de Direito Constitucional e Ciência Política, v. 6, n. 25, p. 25, out./dez. 1998.

. A arguição de descumprimento de preceito fundamental. Disponível em: $<$ http:// gemini.stf.gov.br/netahtml/discurso/homenagem.htm >. Acesso em: 15 nov. 2016.

VIEIRA, Oscar Vilhena. Supremo Tribunal Federal Jurisprudência Política. 2. ed. São Paulo: Malheiros, 2002.

ZAVASCKI, Teori Albino Zavascki. Eficácia das sentenças na jurisdição constitucional. São Paulo: Revista dos Tribunais, 2001.

1 Segundo Caio Mário, a repristinação "é o fenômeno jurídico pelo qual uma lei volta a vigorar após a revogação da lei que a revogou”. (SILVA PEREIRA, Caio Mário. Instituições de direito civil: introdução ao direito civil. teoria geral de direito civil. 21. ed. Rio de Janeiro: Forense, 2005. v. 1).

2 O Superior Tribunal de Justiça teve a oportunidade de decidir a respeito, no sentido de que a repristinação é sempre expressa: "ADMINISTRATIVO. MULTA DE TRÂNSITO. CONTROLADOR ELETRÔNICO DE VELOCIDADE. RESOLUÇÃO No ${ }^{\circ}$ 131/2002. DELIBERAÇÃO No 34, DE 10.05.2002. RESOLUÇÃO N $^{\circ} 141$, DE 16.10.2002. DELIBERAÇÃO N. ${ }^{\circ}$ 29/2001. REPRISTINAÇÃO. IMPOSSIBILIDADE. PRECEDENTES. 1. Não há repristinação quando a lei repristinadora não faça alusão expressa a esse efeito pretendido, consoante o disposto no art. $2^{\circ}, \S 3^{\circ}$, da Lei de Introdução do Código Civil. Precedentes. 2. (Omissis). 3. Recurso especial provido." (REsp 833756/RS, Rel. Ministro MAURO CAMPBELL MARQUES, SEGUNDA TURMA, julgado em 7/8/2008, DJe 26/8/2008). (BRASIL. Superior Tribunal de Justiça. Disponível em: < https://ww2.stj.jus.br/ websecstj/cgi/revista/REJ.cgi/ATC?seq $=4157223 \&$ tipo $=5 \&$ nreg $=200600704126 \& S e q C g r m a S e s s a o=\& C o d$ OrgaoJgdr $=\& d t=20080826 \&$ formato $=P D F \&$ salvar $=$ false $>$. Acesso em: 15 nov. 2016).

3 Lei de Introdução às Normas do Direito Brasileiro, art. $2^{\circ}$, $3^{\circ}$, do Decreto-lei no 4.657, de 4/9/1942, in verbis: "art. $2^{\circ}$. (...) $\S 3^{\circ}$ - Salvo disposição em contrário, a lei revogada não se restaura por ter a lei revogadora perdido a vigência.". BRASIL. Decreto-lei no 4.657, de 04 de setembro de 1942. Lei de Introdução às normas do Direito Brasileiro. Diário Oficial da República Federativa do Brasil, Rio de Janeiro, RJ, 4 set. 1942. 
4 Efeito repristinatório e repristinação não se confundem. A repristinação só acontece de forma expressa, quando o novo texto normativo assim determina. Ela acontece na edição de leis ou de atos administrativos. No efeito repristinatório, não há edição de um novo texto legal, já que o Poder Judiciário reconhece um ato normativo como inconstitucional, e, diante da sua nulidade, ele não revogou validamente a norma anterior, que permanece vigente.

5 O art. 11, § 2 ${ }^{\circ}$, da Lei n ${ }^{\circ}$ 9868/99, prescreve que, na concessão de medida cautelar na Ação Direta de Inconstitucionalidade, haverá a suspensão da vigência da norma questionada, com o retorno da legislação anterior, salvo expressa manifestação em sentido contrário. BRASIL. Lei no 9.868, de 10 de setembro de 1999. Dispõe sobre o processo e julgamento da ação direta de inconstitucionalidade e da ação declaratória de constitucionalidade perante o Supremo Tribunal Federal. Diário Oficial da República do Brasil, Brasília, DF, 10 nov. 1999.

6 Nesse sentido, o precedente do Superior Tribunal de Justiça: "PROCESSUAL CIVIL. TRIBUTÁRIO. MANDADO DE SEGURANÇA. DECLARAÇÃO DE INCONSTITUCIONALIDADE DE LEI REVOGADORA. EFICÁCIA EX TUNC. INAPTIDÃO DA LEI INCONSTITUCIONAL PARA PRODUZIR QUAISQUER EFEITOS. INOCORRÊNCIA DE REVOGAÇÃO. DISTINÇÃO ENTRE DECLARAÇÃO DE INCONSTITUCIONALIDADE E REVOGAÇÃO DE LEI. 1. O vício da inconstitucionalidade acarreta a nulidade da norma, conforme orientação assentada há muito tempo no STF e abonada pela doutrina dominante. Assim, a afirmação da constitucionalidade ou da inconstitucionalidade da norma, mediante sentença de mérito em ação de controle concentrado, tem efeitos puramente declaratórios. Nada constitui nem desconstitui. Sendo declaratória a sentença, a sua eficácia temporal, no que se refere à validade ou à nulidade do preceito normativo, é ex tunc. 2. A revogação, contrariamente, tendo por objeto norma válida, produz seus efeitos para o futuro (ex nunc), evitando, a partir de sua ocorrência, que a norma continue incidindo, mas não afetando de forma alguma as situações decorrentes de sua (regular) incidência, no intervalo situado entre o momento da edição e o da revogação. 3. A não repristinação é regra aplicável aos casos de revogação de lei, e não aos casos de inconstitucionalidade. É que a norma inconstitucional, porque nula ex tunc, não teve aptidão para revogar a legislação anterior, que, por isso, permaneceu vigente. 4 . No caso dos autos, foi declarado inconstitucional o art. $25, \S 2^{\circ}$, da Lei 8.870/94, que determinava a revogação do art. 22, I, da Lei 8.212/90, alterando a base de incidência da contribuição da folha de pagamentos para o faturamento. Não tendo essa lei, porém, face ao reconhecimento de sua inconstitucionalidade, jamais sido apta a realizar o comando que continha, vigeu e vige, desde a sua edição até os dias atuais, o art. 22, inciso I, da Lei 8.212/90, que determina que as empresas de atividade rural recolham a contribuição sobre a folha de salários. 5. Embargos de divergência parcialmente conhecidos, e, nessa parte, não providos" (EREsp 445.455/BA, $2^{\text {a }}$ Turma, Rel. Min. João Otávio de Noronha, j. em 23/03/2004 - g.n.). BRASIL. Superior Tribunal de Justiça. Disponível em: <https://ww2.stj.jus.br/processo/ revista $/$ documento $/$ mediado $/$ componente $=$ ATC $\&$ sequencial $=2133903 \&$ num_registro $=200400734360 \& d$ ata $=20051205 \&$ tipo $=5 \&$ formato $=$ PDF $>$. Acesso em: 15 nov. 2016.

7 O Supremo Tribunal Federal pode decidir pela não aplicação do efeito repristinátorio, com respaldo, no art. 27 da Lei 9.868/99 e no art. 11 da Lei 9.882/99, modulando os efeitos da declaração de inconstitucionalidade: "Ao declarar a inconstitucionalidade de lei ou ato normativo, e tendo em vista razões de segurança jurídica ou de excepcional interesse social, poderá o Supremo Tribunal Federal, por maioria de dois terços de seus membros, restringir os efeitos daquela declaração ou decidir que ela só tenha eficácia a partir de seu trânsito em julgado ou de outro momento que venha a ser fixado". BRASIL. Lei n ${ }^{\circ}$ 9.868, de 10 de setembro de 1999. Dispõe sobre o processo e julgamento da ação direta de inconstitucionalidade e da ação declaratória de constitucionalidade perante o Supremo Tribunal Federal. Diário Oficial da República do Brasil, Brasília, DF, 10 nov. 1999.

8 O controle concentrado é exercido mediante provocação dos legitimados previstos pelo art. 103 da Constituição Federal. Pode acontecer de não existir pedido expresso de reconhecimento de inconstitucionalidade de lei ou ato normativo anterior. Surgem três possibilidades: o STF afasta de ofício o efeito repristinatório; determina a emenda da petição inicial para ser suprida a omissão ou, simplesmente, não conhece da ação. Os julgados mais recentes optaram por afastar o efeito repristinatório (ADIs 2154, 2258 e 3660). Nesse sentido: "Conjugando os entendimentos fixados pelo Tribunal de que, no âmbito do controle em abstrato da constitucionalidade, o requerente deve impugnar todo o complexo normativo supostamente inconstitucional, inclusive as normas revogadas que poderão ser eventualmente repristinadas pela declaração de inconstitucionalidade das normas revogadoras, e de que o processo de controle abstrato destina-se, fundamentalmente, à aferição da constitucionalidade de normas pós-constitucionais, concluiu-se que a impugnação deveria abranger apenas a cadeia de normas revogadoras e 
revogadas até o advento da Constituição de 1988. Asseverou-se, ademais, que a exigência de impugnação de toda a cadeia normativa supostamente inconstitucional poderia até mesmo ser relativizada, haja vista a possibilidade de o Tribunal deliberar a respeito da modulação do próprio efeito repristinatório da declaração de inconstitucionalidade (Lei 9.868/99, art. 11, §2 , c/c o art. 27)". (ADI 3660, Rel. Min. Gilmar Mendes). "No que se refere à norma final do $\S 2^{\circ}$ do art. 11 da Lei 9.868/99 que prevê que a "concessão da medida cautelar torna aplicável a legislação anterior, salvo expressa manifestação em sentido contrário", o Tribunal, por maioria, julgou improcedente o pedido formulado. Salientou-se, inicialmente, que a ação direta foi instituída como instrumento de salvaguarda da higidez da ordem jurídica e não para a tutela de pretensões de direito dos sujeitos legitimados para propô-la e que, em razão disso, a recepção do princípio do pedido no processo objetivo da jurisdição constitucional há de ser dimensionada a partir dessa perspectiva institucional do sistema de controle abstrato de normas. Tendo isso em conta, entendeu-se, na linha adotada pela doutrina portuguesa e pequena parte da brasileira, que o Tribunal pode sobrepor apreciar incidentemente a constitucionalidade da lei precedente à impugnada para, julgando-a igualmente inválida, impedir sua revivescência decorrente da declaração de inconstitucionalidade da que a tenha revogado. Ressaltou-se que a recusa da repristinação se baseará em juízo similar ao da declaração incidente de inconstitucionalidade de norma cuja validade seja prejudicial da decisão principal a tomar, a qual sempre se pode dar de oficio e que nada exclui possa ocorrer no julgamento de uma ADI, em que um mesmo tribunal, como o STF, cumule as funções de órgão exclusivo do controle abstrato com o de órgão de cúpula do sistema difuso. Vencido, nessa parte, o Min. Marco Aurélio que declarava a inconstitucionalidade da expressão impugnada por considerar que a possibilidade de o Tribunal extravasar os limites objetivos da própria ADI, declarando restabelecida ou não a legislação anterior, contrariaria os princípios da segurança jurídica e o de que o Judiciário atua apenas mediante provocação. ADI 2154/DF e ADI 2258/DF, rel. Min. Sepúlveda Pertence, 14.2.2007. (ADI-2154) (ADI-2258)" - Informativo STF no 456, título "ADI e Lei 9.868/99 - 4". BRASIL. Supremo Tribunal Federal. Informativo STF. Disponível em: < http://www.stf.jus.br/arquivo/informativo/documento/informativo456.htm>. Acesso em: 15 nov. 2016).

9 Lei 9.868, de 10 de novembro de 1999, art. 11: "Concedida a medida cautelar, o Supremo Triunal Federal fará publicar em seção especial do Diário Oficial da União e do Diário da Justiça da União a parte dispositiva da decisão, no prazo de dez dias, devendo solicitar as informações à autoridade da qual tiver emanado o ato, observando-se, no que couber, o procedimento estabelecido na Seção I deste Capítulo. [...].§ 2o A concessão da medida cautelar torna aplicável a legislação anterior acaso existente, salvo expressa manifestação em sentido contrário". BRASIL. Lei n ${ }^{\circ}$ 9.868, de 10 de setembro de 1999. Dispõe sobre o processo e julgamento da ação direta de inconstitucionalidade e da ação declaratória de constitucionalidade perante o Supremo Tribunal Federal. Diário Oficial da República do Brasil, Brasília, DF, 10 nov. 1999.

10 CLÈVE, Clèmersom Merlin. A fiscalização abstrata da constitucionalidade no direito brasileiro. 2. ed. São Paulo: Revista dos Tribunais, 2000. p. 249.

11 Controle abstrato é realizado em tese, independentemente da existência de uma lide, em quatro ações: ação direta de inconstitucionalidade genérica, ação direta de inconstitucionalidade por omissão, ação declaratória de constitucionalidade e arguição de descumprimento de preceito fundamental. Já o controle difuso é aquele realizado por qualquer juiz ou tribunal em qualquer processo judicial, como questão prejudicial à análise de outra principal.Sobre o tema vide a obra de FERREIRA, Olavo Alves. Controle de constitucionalidade e seus efeitos. 3. ed. Salvador: Juspodivm, 2016.

12 O Plenário do Conselho Nacional de Justiça decidiu, por unanimidade, em sessão virtual extraordinária, realizada dia 3 de março de 2016, que o Código de Processo Civil de 2015 passaria a vigorar dia 18 de março de 2016. O julgamento foi aberto na $226^{\mathrm{a}}$ Sessão Ordinária do Conselho, na terça-feira $\left(1^{\circ} / 3\right)$, e continuou em ambiente virtual por decisão da Presidência do Conselho, após a Corregedora Nacional de Justiça, Ministra Nancy Andrighi, pedir mais prazo para analisar melhor a manifestação encaminhada ao CNJ pela Ordem dos Advogados do Brasil (OAB). (BRASIL. Conselho Nacional de Justiça. $\mathrm{CNJ}$ responde à $\mathrm{OAB}$ e decide que vigência do novo CPC começa em 18 de março. Disponível em: < http://www.cnj.jus.br/noticias/cnj/81698-cnj-responde-a-oab-e-decide-que-vigencia-do-novo-cpc-comeca-em-18-de-marco >. Acesso em: 15 nov. 2016).

13 BRASIL. Lei no 13.105, de 16 de março de 2015. Código de Processo Civil. Diário Oficial da República Federativa do Brasil, Brasília, DF, 16 mar. 2015. "Art. 9 . Não se proferirá decisão contra uma das partes sem que ela seja previamente ouvida. Parágrafo único. O disposto no caput não se aplica: I - à tutela provisória de urgência; II - às hipóteses de tutela da evidência previstas no art. 311, incisos II e III; III - à decisão prevista no art. 701". 
14 BRASIL. Lei no 13.105, de 16 de março de 2015. Código de Processo Civil. Diário Oficial da República Federativa do Brasil, Brasília, DF, 16 mar. 2015. "Art. 10. O juiz não pode decidir, em grau algum de jurisdição, com base em fundamento a respeito do qual não se tenha dado às partes oportunidade de se manifestar, ainda que se trate de matéria sobre a qual deva decidir de ofício".

15 As chamadas "decisões-surpresa" são aquelas que violam a exigência de contraditório prévio, como delimitado pelos artigos $9^{\circ}$ e 10 referidos linhas acima. Antes de decidir qualquer tema, como regra, as partes devem ter a oportunidade de manifestação.

16 RAMOS, Elival da Silva. A inconstitucionalidade das leis: vício e sanção. São Paulo: Saraiva, 1994. p. 63-4.

17 Adotamos a lição do professor Celso Ribeiro Bastos que "toda a norma infringente da Constituição é nula" (BASTOS, Celso Ribeiro. Curso de direito constitucional. 21. ed. São Paulo: Saraiva, 2000. p. 389). Entendem que a norma inconstitucional é nula, entre outros: José Cretella Júnior (CRETELLA JUNIOR, José. Elementos de direito constitucional. 4. ed. São Paulo: Editora Revista dos Tribunais, 2000. p. 100); Geraldo Ataliba (ATALIBA, Geraldo. Regime tributário e estado de direito. Disponível em: <www.trf3.gov.br/palestra03.htm >. Acesso em: 28 set. 2001); Alfredo Buzaid (BUZAID, Alfredo. Da ação direta de declaração de inconstitucionalidade. São Paulo: Saraiva, 1958. p. 132); José Afonso da Silva (SILVA, José Afonso da. Curso de direito constitucional positivo. 11. ed. São Paulo: Malheiros, 1996. p. 55); Ada Pellegrini Grinover (GRINOVER, Ada Pellegrini. Controle da constitucionalidade. Revista Forense, v. 94, n. 341, p. 3-12, 1998. p. 12); Gilmar Ferreira Mendes (MENDES, Gilmar Ferreira. Jurisdição Constitucional. 2. ed. São Paulo: Saraiva, 1998. p. 256); Clèmerson Merlin Clève (CLÈVE, Clemèrson Merlin. A fiscalização abstrata de constitucionalidade. 2. ed. São Paulo: Revista dos Tribunais, 2000. p. 249); André Ramos Tavares (TAVARES, André Ramos. Tribunal e jurisdição constitucional. São Paulo: Celso Bastos Editor, 1998. p. 121); Luiz Alberto David Araújo e Vidal Serrano Nunes Júnior (ARAÚJO, Luiz Alberto David; NUNES JÚNIOR, Vidal Serrano. Curso de direito constitucional. 4. ed. São Paulo: Saraiva, 2001. p. 25); Michel Temer (TEMER, Michel. Elementos de direito constitucional. 12. ed. São Paulo: Malheiros Editores, 1996. p. 40); e Juliano Taveira Bernardes (BERNARDES, Juliano Taveira. Controle abstrato de constitucionalidade: elementos materiais e princípios processuais. São Paulo: Saraiva, 2004. p. 347). No mesmo sentido é o entendimento do STF: RE-93173/SP, Relator Min. Firmino Paz, Julgamento 15/6/1982 - 2a Turma; RE-56192 / RN, Relator(a) Min. CÂNDIDO MOTTA, Julgamento 23/3/1965 - PRIMEIRA TURMA (BRASIL. Supremo Tribunal Federal. RE 93173 / SP. Disponível em: <http://www.lexml.gov.br/urn/urn:lex:br:supremo.tribunal.federal;tu rma.2:acordao;re:1982-06-15;93173->. Acesso em: 15 nov. 2016). ADIMC-1434/SP AÇÃO DIRETA DE INCONSTITUCIONALIDADE - MEDIDA CAUTELAR, Relator Min. CELSO DE MELLO; Julgamento 20/8/1996 - Tribunal Pleno; (BRASIL. Supremo Tribunal Federal. Ação direta de inconstitucionalidade Disponível em: <http://redir.stf.jus.br/paginadorpub/paginador.jsp?docTP=AC\&docID=347055>. Acesso em: 15 nov. 2016).

18 Não se pode olvidar que entre os princípios implícitos e os expressos "não se pode falar em supremacia". É dizer, ambos retiram fundamento de validade do mesmo texto jurídico, segundo lição de Paulo de Barros Carvalho (CARVAlHO, Paulo de Barros. Curso de direito tributário. São Paulo: Saraiva, 1996. p. 90).

19 "O sistema de controle de constitucionalidade funciona como critério identificador da sanção de inconstitucionalidade acolhida pelo ordenamento. Assim, a sanção de nulidade exige a presença do controle via incidental, apresentando a decisão que constata a incidência da sanção aparência de uma retroatividade radical, por redundar na negativa de efeitos ab initio ao ato impugnado. Já a sanção de anulabilidade aparece necessariamente associada ao controle concentrado, em que se produzam decisões anulatórias com eficácia erga omnes e não retroativas ou com retroatividade limitada" (RAMOS, Elival Silva. A inconstitucionalidade das leis. São Paulo: Saraiva, 1994. p. 94). Canotilho concorda com os ensinamentos acima: "No caso do judicial review o efeito típico é o da nulidade e não simples anulabilidade" (op. cit., p. 875). Vale lembrar que o ordenamento constitucional pátrio adotou o sistema híbrido ou misto, isto é, temos o controle difuso e concentrado.

20 RAMOS, Elival da Silva, op. cit., p. 94.

21 Ibidem, p. 94.

22 CANOTILHO, J. J. Gomes. Direito constitucional. 4. ed. Coimbra: Livraria Almedina, [19--]. p. 875.

23 RAMOS, Elival da Silva, op. cit., p. 128.

24 Constituição Federal: Artigo 52, X - "suspender a execução, no todo ou em parte, de lei declarada inconstitucional por decisão definitiva do Supremo Tribunal Federal"; e 103, § 2. "Declarada a inconstitucionalidade 
por omissão de medida para tornar efetiva norma constitucional, será dada ciência ao Poder competente para a adoção das providências necessárias e, em se tratando de órgão administrativo, para fazê-lo em trinta dias"; e art. 102. "Compete ao Supremo Tribunal Federal, precipuamente, a guarda da Constituição, cabendo-lhe: I - processar e julgar, originariamente: a) a ação direta de inconstitucionalidade de lei ou ato normativo federal ou estadual e a Ação Declaratória de Constitucionalidade de lei ou ato normativo federal; e 102, III - julgar, mediante recurso extraordinário, as causas decididas em única ou última instância, quando a decisão recorrida:...b) declarar a inconstitucionalidade de tratado ou lei federal"; e art. 97. "Somente pelo voto da maioria absoluta de seus membros ou dos membros do respectivo órgão especial poderão os tribunais declarar a inconstitucionalidade de lei ou ato normativo do poder público". BRASIL. Constituição da República Federativa do Brasil de 1988. Diário Oficial da República Federativa do Brasil, Brasília, DF, 5 out. 1988.

25 Lembramos que, na Constituição, não há palavras inúteis, já que aplicável a lição de Carlos Maximiliano: "interpretem-se as disposições de modo que não pareça haver palavras supérfluas e sem força operativa". (MAXIMILIANO, Carlos. Hermenêutica e aplicação do direito. 7. ed. São Paulo: Editora Livraria Freitas Bastos S/A, 1961. p. 312).

26 "O processo meramente declaratório visa apenas à declaração da existência ou inexistência da relação jurídica". (CINTRA, Antonio Carlos de Araújo; GRINOVER Ada Pellegrini; DINAMARCO, Cândido Rangel. Teoria geral do processo. 10. ed. São Paulo: Malheiros Editores, 1994. p. 302). Entendemos que é aplicável o conceito acima aos processos de controle abstrato, já que a inconstitucionalidade é uma relação jurídica.

27 Canotilho aponta: "Fala-se em efeito declarativo quando a entidade controlante se limita a declarar a nulidade pré-existente do acto normativo. O acto normativo é absolutamente nulo (null and void), e, por isso, o juiz ou qualquer outro órgão de controlo 'limita-se' a reconhecer declarativamente a sua nulidade. É o regime típico do controle difuso" (op. cit., p. 875).

28 Sobre o tema vide nosso FERREIRA, Olavo Augusto Vianna Alves. Controle de constitucionalidade e seus efeitos. 2. ed. São Paulo: Método, 2005. Walber de Moura Agra afirma que, em alguns casos, a decisão de inconstitucionalidade é constitutivo-negativa, "tornando-se o ato inconstitucional por vontade do Poder Judiciário, dimensionando-se o STF como um órgão legislativo negativo" (AGRA, Walber de Moura. Curso de direito constitucional. Rio de Janeiro: Forense, 2006. p. 495).

29 BARBOSA, Rui. Os atos inconstitucionais do Congresso e do executivo. In: Rio de Janeiro: Casa de Rui Barbosa, 1962. p. 70.

30 WILLOUGHBY, Westel Woodbury. The Constitutional Law of the United States. New York: [S.1.], 1910. v. 1. p. 9-10. Vale observar que consolidação do controle de constitucionalidade atribuiu-se à decisão proferida no caso Marbury vs. Madison, em 1803: "Ou a Constituição é a lei superior, intocável por meios ordinários, ou ela está no mesmo nível que os atos legislativos ordinários, e, como os outros atos, é alterável quando a legislatura aprouver alterá-los. Se a primeira parte da alternativa é verdadeira, então um ato legislativo contrário à Constituição não é lei; se a última é verdadeira, então as Constituições escritas são tentativas absurdas por parte do povo de limitar um poder por sua própria natureza ilimitável". Afirma ainda Cappelletti que "se é verdadeiro que hoje todas as constituições modernas do mundo ocidental tendem já a afirmar o seu caráter de constituições rígidas e não mais flexíveis, é também verdadeiro, no entanto que este movimento, de importância fundamental e de alcance universal, foi efetivamente, iniciado pela Constituição norte-amerticana de 1787 e pela corajosa jurisprudência que se aplicou" (CAPPELLETTI, Mauro. O controle judicial de constitucionalidade das leis no direito comparado. 2. ed. Porto Alegre: Fabris, 1992. p. 47-48).

31 Vide notas de rodapé 15 e 17 citando os autores e precedentes que acolheram o dogma da nulidade do ato inconstitucional.

32 "A QUESTÃO DA EFICÁCIA REPRISTINATÓRIA DA DECLARAÇÃO DE INCONSTITUCIONALIDADE "IN ABSTRACTO". - A declaração final de inconstitucionalidade, quando proferida pelo Supremo Tribunal Federal em sede de fiscalização normativa abstrata, importa - considerado o efeito repristinatório que lhe é inerente - em restauração das normas estatais anteriormente revogadas pelo diploma normativo objeto do juízo de inconstitucionalidade, eis que o ato inconstitucional, por ser juridicamente inválido (RTJ 146/461-462), sequer possui eficácia derrogatória. Doutrina. Precedentes (STF)", (ADI 2867, Relator(a): Min. CELSO DE MELLO, Tribunal Pleno, julgado em 3/12/2003, DJ 9-2-2007 PP-00016 EMENT VOL-02263-01 PP-00067 RTJ VOL-00202-01 PP-00078).

33 Na jurisprudência do Supremo Tribunal Federal, o efeito repristinatório surgiu antes da Constituição de 1988, no controle abstrato nos julgamentos: i) em 26 de fevereiro de 1981, da Medida Cautelar da representação de 
inconstitucionalidade ${ }^{\circ}$ 1077, cujo Relator foi o Ministro Moreira Alves; e ii) em 23 de outubro de 1986, da Medida Cautelar da representação de inconstitucionalidade no 1356/AL, cujo Relator foi o Ministro Francisco Rezek: "Representação por inconstitucionalidade. Suspensão liminar da eficácia da lei. Consequências. A suspensão liminar da eficácia da lei torna aplicável a legislação anterior acaso existente, e não impede que se edite nova lei, na conformidade das regras constitucionais inerentes ao processo legislativo" (STF Pleno, Rp 1356 MC-revogação, Relator: Min. FRANCISCO REZEK, julgado em 23/10/1986, DJ 14-11-1986 PP-22148 EMENT VOL-01441-01 PP-00123). Convém ressaltar que estes julgados não se dedicaram ao aprofundamento teórico do tema em estudo.

34 MENDES, Gilmar Ferreira. Jurisdição constitucional. 2. ed. São Paulo: Saraiva, 1998. p. 256; CLÈVE, Clèmerson Merlin. A fiscalização abstrata de constitucionalidade no direito brasileiro. 2. ed. São Paulo: Revista dos Tribunais, 2000. p. 246.

35 O Tribunal Constitucional "não tem de decidir expressis verbis efeitos repristinatórios nem tem de especificar quais as normas repristinadas" (CANOTILHO, José Joaquim Gomes. Direito constitucional. 4. ed. Coimbra: Livraria Almedina, [19--]. p. 987).

36 Constituição da República Portuguesa, artigo 282 (Efeitos da declaração de inconstitucionalidade ou de ilegalidade), "1. A declaração de inconstitucionalidade ou de ilegalidade com força obrigatória geral produz efeitos desde a entrada em vigor da norma declarada inconstitucional ou ilegal e determina a repristinação das normas que ela, eventualmente, haja revogado". PORTUGAL. Constituição da República Portuguesa. Portugal, 2 abr. 1976.

37 Onde o Tribunal Constitucional Federal detém competência para indicar com efeitos vinculantes se o efeito repristinatório é ou não aplicável. Neste sentido, MEDEIROS, Rui. A decisão de inconstitucionalidade. Lisboa: Universidade Católica Editora, 1999. p. 665.

38 Sendo que a Corte decide sobre a incidência do efeito repristinatório, conforme leciona José Adércio Leite Sampaio (SAMPAIO, José Adércio Leite. A Constituição reinventada pela jurisdição constitucional. Belo Horizonte: Del Rey, 2002. p. 224).

39 Jörn Ipsen afirma que se trata de uma evidência dogmática no quadro da teoria da nulidade da lei inconstitucional. Rechtsfolgen der Verfassungswidrigkeit von Norm umd Einzelakt, Baden-Baden, p. 258. 1980,

40 Expressão sugerida pelo Amigo e Professor Andrey Borges de Mendonça, Procurador da República.

41 MEDEIROS, op. cit., p. 652.

42 "A norma anterior não chegou juridicamente a cessar a sua vigência. Por isso, e como sempre, ela mantém-se em vigor e continua a ser aplicável após a decisão de inconstitucionalidade" (MEDEIROS, op. cit., p. 652).

43 Neste sentido, Guilherme Peña de Moraes, (MORAES, Peña de Moraes. Direito Constitucional: teoria da constituição. 2. ed. Rio de Janeiro: Editora Lumen Juris, 2004 p. 248, nota de rodapé 248); e Juliano Taveira Bernardes (BERNARDES, Juliano Taveira. Efeitos das normas constitucionais no sistema normativo brasileiro. Porto Alegre: Sergio Antonio Fabris Editor, 2002. p. 41). Este doutrinador trata de uma aparente ligação do efeito repristinatório com a repristinação. Em sentido contrário alguns julgados do STF tratam das expressões para designar o mesmo instituto, vide RE 114.689-3, Relator Ministro Oscar Corrêa, j. 11/12/1987; ADIN 2574, Relator Ministro Carlos Velloso, DJ 29/08/2003; ADIN 2847, Relator Ministro Carlos Velloso, J. 05/8/2004; ADI 2.154 e ADI 2.258, Rel. Min. Sepúlveda Pertence, julgamento em 14/2/07, Informativo 456. Luís Roberto Barroso emprega as expressões como sinônimas: "a premissa da não-admissão dos efeitos válidos decorrentes do ato inconstitucional conduz, inevitavelmente, à tese da repristinação da norma revogada. É que, a rigor lógico, sequer se verificou a revogação no plano jurídico. De fato, admitir-se que a norma anterior continue a ser tida por revogada importará na admissão de que a lei inconstitucional inovou na ordem jurídica, submetendo o direito objetivo a uma vontade que era viciada desde a origem. Não há teoria que possa resistir a essa contradição", BARROSO, Luís Roberto Barroso. Interpretação e aplicação da constituição. 3. ed. São Paulo: Saraiva, 1996. p. 92-93.

44 BASTOS, Celso Ribeiro. Hermenêutica e interpretação constitucional. São Paulo: Celso Bastos Editor, 1997. p. 117.

45 CLÈVE, Clèmersom Merlin. A fiscalização abstrata da constitucionalidade no direito brasileiro. 2. ed. São Paulo: Revista dos Tribunais, 2000. p. 250, nota de rodapé 259.

46 Ibidem, p. 250. 
47 FRANCO, Amedeo. Considerazioni sulla dichiarazione di inconstituzionalità di disposizioni espressamente abrogatrici. Giur: Cost, 1974. II. p. 3449-3450.

48 MEDEIROS, op. cit., p. 653.

49 Segundo leciona Paulo de Barros Carvalho, o princípio da segurança jurídica dirige-se "à implantação de um valor específico, qual seja o de coordenar o fluxo das interações interhumanas, no sentido de propagar no seio da comunidade social o sentimento de previsibilidade quanto aos efeitos jurídicos da conduta. Tal sentimento tranquiliza os cidadãos, abrindo espaço para o planejamento de ações futuras, cuja disciplina jurídica conhecem, confiantes que estão no modo pelo qual a aplicação das normas do direito se realiza", CARVALHO, Paulo de Barros. Curso de direito tributário. 9. ed. São Paulo: Saraiva, 1996. p. 92. Dimitri Dimoulis afirma que a "segurança jurídica é o resultado (subjetivo e de cunho psicológico) de uma configuração jurídica cujo elemento principal (objetivo) é a previsibilidade das conseqüências jurídicas" (DIMOULIS, Dimitri. Positivismo jurídico: introdução a uma teoria do direito e defesa do pragmatismo jurídico-político. São Paulo: Método, 2006. p. 198).

50 "Além de tudo, como conclui Radbruch, um direito incerto é também um direito injusto, pois não é capaz de assegurar a fatos futuros tratamento igual” (Ministro Moreira Alves, STF, Ação Declaratória de Constitucionalidade n. 1-1/DF).

51 A expressão é empregada por Rui Medeiros. (MEDEIROS, op. cit., p. 655).

52 MEDEIROS, op. cit., p. 655.

53 Art. 11, § 2. ${ }^{\circ}$, Lei n. 9.868/99 - "A concessão da medida cautelar torna aplicável a legislação anterior acaso existente, salvo expressa manifestação em sentido contrário".

54 "A declaração de inconstitucionalidade in abstracto, de um lado, e a suspensão cautelar de eficácia do ato reputado inconstitucional, de outro, importam - considerado o efeito repristinatório que lhes é inerente - em restauração das normas estatais revogadas pelo diploma objeto do processo de controle normativo abstrato", ADIn 2.215-PE (Medida Cautelar), Rel. Min. Celso de Mello, Brasília, 17 de abril de 2001.

55 Logicamente, julgando improcedente a ação declaratória.

56 Neste sentido, Supremo Tribunal Federal: RTJ 96/496, 1981, p. 508, Rep. N. 980-SP, Relator Ministro Moreira Alves; Adin 221-DF, Relator Ministro Moreira Alves, RTJ 151/331, 1995.

57 Neste sentido, RAMOS, op. cit., p. 238.

58 Constituição Federal: “Art. 23. É competência comum da União, dos Estados, do Distrito Federal e dos Municípios: I - zelar pela guarda da Constituição, das leis e das instituições democráticas e conservar o patrimônio público".

59 Constituição Federal: "Art. 85. São crimes de responsabilidade os atos do Presidente da República que atentem contra a Constituição Federal".

60 Uma situação poderá ser imaginada: o Chefe do Poder Executivo verifica a inconstitucionalidade da norma que dispõe sobre o cálculo de um tributo, tal como fez o STF no julgado anteriormente citado (RE 260.670-7-SP, Relator Ministro Sepúlveda Pertence, DJ 26/05/2000). Entendemos que poderá afastá-la e aplicar à anterior, perfeitamente válida, evitando, dessa forma, a prática de crime de responsabilidade, previsto no artigo 85 da CF.

61 Sobre as diferenças entre cautelar, tutela antecipada e liminar no controle abstrato de constitucionalidade vide nosso FERREIRA, Olavo Augusto Vianna Alves. Controle de constitucionalidade e seus efeitos. 2. ed. São Paulo: Método, 2005.

62 CLÈVE, Clèmerson Merlin. A fiscalização abstrata da constitucionalidade no direito brasileiro. 2. ed. São Paulo: Revista dos Tribunais, 2000. p. 250.

63 ADIn 2.215-PE (Medida Cautelar), Rel. Min. Celso de Mello, 17/04/2001. No mesmo sentido ADI 2.132/ MC, Ministro Moreira Alves, DJ de 05/04/02; ADI 2.242, Ministro Moreira Alves, DJ de 19/12/01; ADI 3218 / CE, Relator Ministro Eros Grau, j. 7/12/2004; ADI 2883/DF, rel. Min. Gilmar Mendes, 30/8/2006.

64 "Conjugando os entendimentos fixados pelo Tribunal de que, no âmbito do controle em abstrato da constitucionalidade das leis e dos atos normativos, o requerente deve impugnar todo o complexo normativo supostamente inconstitucional, inclusive as normas revogadas que poderão ser eventualmente repristinadas pela declaração de inconstitucionalidade das normas revogadoras, e de que o processo de controle abstrato destina-se, fundamentalmente, à aferição da constitucionalidade de normas pós-constitucionais, concluiu-se que a impugnação deveria abranger apenas a cadeia de normas revogadoras e revogadas até o advento da Constituição de 1988. Asseverou-se, ademais, que a exigência de impugnação de toda a cadeia normativa supostamente inconstitu- 
cional poderia até mesmo ser relativizada, haja vista a possibilidade de o Tribunal deliberar a respeito da modulação do próprio efeito repristinatório da declaração de inconstitucionalidade (Lei 9.868/99, art. 11, $\S 2^{\circ}, \mathrm{c} / \mathrm{c}$ o art. 27). Assim, quanto à Lei 340/82, considerou-se que não se poderia exigir sua impugnação por ser norma anterior à CF/88 e, em relação à Lei 1.135/91, observou-se que o Procurador-Geral da República, aditara o pedido inicial, em seu parecer, para incluí-la no objeto da ação". ADI 3660/MS, rel. Min. Gilmar Mendes, 18.6.2007.

65 SARMENTO, Daniel. A eficácia temporal das decisões no controle de constitucionalidade, hermenêutica e jurisdição constitucional. Belo Horizonte: Del Rey, 2001. p. 37.

66 Em Portugal, o efeito repristinatório não é aceito incondicionalmente. "Tendo em conta a sua razão de ser é lógico que: "(i) existam esses efeitos quando entre nenhuma norma e a norma repristinada, seja esta a solução mais razoável; (ii) não existam quando a norma declarada inconstitucional não tiver revogado qualquer norma anterior. No caso de a norma repristinada ser inconstitucional não está vedada ao TC a possibilidade de conhecer dessa inconstitucionalidade para fundamentar nela a recusa de efeitos repristinatórios (cfr. Ac. TC 56/84). Mais duvidoso (por violar o princípio do pedido) é a possibilidade de o TC conhecer e declarar a inconstitucionalidade das normas repristinadas (Ac. 452/95, DR, II, 21-11)”. CANOTILHO, op. cit., p. 988. No mesmo sentido é o entendimento de MEDEIROS, op. cit., p. 660.

67 Ibidem, mesma página. Sobre o tema vide nosso Controle de constitucionalidade e seus efeitos. 2. ed. São Paulo: Método, 2005.

68 Controle difuso de constitucionalidade é aquele exercido pelos magistrados em geral nas ações individuais e coletivas.

69 MENDES, Gilmar Ferreira. Jurisdição constitucional. 2. ed. São Paulo: Saraiva, 1998. p. 256; CLÈVE, Clèmerson Merlin. A fiscalização abstrata de constitucionalidade. 2. ed. São Paulo: Revista dos Tribunais, 2000. p. 246.

70 No sentido da afirmação o precedente do Supremo Tribunal Federal que segue: "PROCESSUAL CIVIL. TRIBUTÁRIO. FUNDAMENTO NÃO IMPUGNADO. SÚMULA 182/STJ. FUNRURAL. DECLARAÇÃO DE INCONSTITUCIONALIDADE ACARRETA A REPRISTINAÇÃO DA NORMA REVOGADA PELA LEI VICIADA. CÁLCULO DA EXAÇÃO NOS MOLDES DA LEI REVOGADA. EFEITO LÓGICO DECORRENTE DA REPRISTINAÇÃO. EXEGESE DO RESP 1.136.210/PR, SUBMETIDO AO REGIME DOS RECURSOS REPETITIVOS (ART. 543-C DO CPC). SÚMULA 83/STJ. MULTA. 1. De início, observa-se que as razões do agravo regimental não impugnam o fundamento da decisão agravada quanto à ausência de omissão no julgado, afastando a preliminar de violação do art. 535 do CPC. Incidência da Súmula 182/STJ. 2. Nos termos da jurisprudência desta Corte, havendo declaração de inconstitucionalidade de uma lei, volta a vigorar a lei revogada. 3. A repristinação da lei anterior impõe o cálculo da exação nos moldes da lei revogada, sendo devida a restituição tão somente da diferença existente entre a sistemática instituída pela lei inconstitucional e a prevista na lei repristinada, caso haja". Entendimento firmado no REsp 1.136.210/PR, da relatoria do Min. Luiz Fux, submetido ao regime dos recursos repetitivos (art. 543-C do CPC). 4. "O efeito repristinatório é uma consequência da declaração de inconstitucionalidade, pois a lei declarada inconstitucional não possui eficácia derrogatória. Ocorre a reentrada em vigor da norma aparentemente revogada. Dessa forma, decidida a lide nos limites em que foi proposta, não há falar em ofensa aos arts. 128 e 460 do CPC, tendo em vista que a fundamentação não é critério apto para a avaliação de julgamento ultra petita" (AgRg no REsp 1.495.282/PR, Rel. Ministro MAURO CAMPBELL MARQUES, SEGUNDA TURMA, julgado em 05/03/2015, DJe 11/03/2015). 5. O STJ entende que deve ser aplicada a multa prevista no art. $557, \S 2^{\circ}$, do $\mathrm{CPC}$ nos casos em que a parte insurgir-se quanto à tema já decidido em julgado submetido à sistemática do art. 543-C do CPC. Agravo regimental conhecido em parte e improvido com aplicação de multa. (AgRg no REsp 1576951/PR, Segunda Turma, Relator Min. Humberto Martins, j. em 10/03/2016, DJe de 17/03/2016).

71 "De facto, se a norma inconstitucional é inválida ab initio e como tal deve ser considerada, não se pode reconhecer efeitos jurídicos à norma inconstitucional revo-gatória ou, pelo menos, o juízo de inconstitucionalidade, mesmo quando proferido em sede de fiscalização concreta, destrói retroactivamente tais efeitos". MEDEIROS, op. cit., p. 656. O Tribunal Constitucional lusitano já aplicou tal entendimento Acórdão n. 103/87 e n. 490/89. 
72 "ITBI: progressividade: L. 11.154/91, do Município de São Paulo: inconstitucionalidade. A inconstitucionalidade, reconhecida pelo STF (RE 234.105), do sistema de alíquotas progressivas do ITBI do Município de São Paulo (L. 11.154/91, art. 10, II), atinge esse sistema como um todo, devendo o imposto ser calculado, não pela menor das alíquotas progressivas, mas na forma da legislação anterior, cuja eficácia, em relação às partes, se restabelece com o trânsito em julgado da decisão proferida neste feito". RE 260.670-7-SP, Relator Ministro Sepúlveda Pertence, DJ 26/5/2000.

73 A expressão é empregada por MEDEIROS, op. cit., p. 655.

74 MEDEIROS, op. cit., p. 655.

75 "TRIBUTÁRIO. PIS. LEI COMPLEMENTAR N. 7/70: LEGITIMIDADE DA COBRANÇA APÓS A DECLARAÇÃO DE INCONSTITUCIONALIDADE DOS DECRETOS-LEIS 2.445/88 E 2.449/88. RESOLUÇÃO DO SENADO FEDERAL 49/95. EFEITO REPRISTINATÓRIO. 1. O Supremo Tribunal Federal possui o entendimento consolidado no sentido de que é legítima a cobrança da contribuição ao PIS, na forma disciplinada pela Lei Complementar 07/70, no período compreendido entre a declaração de inconstitucionalidade dos Decretos-leis 2.445/88 e 2.449/88 e a entrada em vigor da MP 1.212/95. Precedentes. 2. A Resolução do Senado Federal 49/95, que conferiu efeitos erga omnes à decisão proferida no RE 148.754/RJ, redator para o acórdão Min. Francisco Rezek, Tribunal Pleno, DJ 04.03.1994, fez exsurgir a LC 07/70, numa espécie de efeito repristinatório, de forma que tal norma voltasse a produzir seus efeitos. Precedente. 3. Agravo regimental improvido". STF, AI 677191 AgR, Relator(a): Min. ELLEN GRACIE, Segunda Turma, julgado em 08/06/2010, DJe-116 DIVULG 24-06-2010 PUBLIC 25-06-2010 EMENT VOL-02407-06 PP-01355.

76 CPC/2015: "Art. $9^{\circ}$ Não se proferirá decisão contra uma das partes sem que ela seja previamente ouvida. Parágrafo único. O disposto no caput não se aplica: I - à tutela provisória de urgência; II - às hipóteses de tutela da evidência previstas no art. 311, incisos II e III; III - à decisão prevista no art. 701”. As hipóteses do art. $9^{\circ}$, entretanto, não são taxativas. Há pelo menos uma situação que o juiz atua de ofício antes de formada a relação jurídica processual e profere decisão sem sujeitá-la ao contraditório. Assim, o texto do art. $63, \S 3^{\circ}, \mathrm{CPC} / 2015$ : "Antes da citação, a cláusula de eleição de foro, se abusiva, pode ser reputada ineficaz de ofício pelo juiz, que determinará a remessa dos autos ao juízo do foro de domicílio do réu". CPC/2015: Art. 10. "O juiz não pode decidir, em grau algum de jurisdição, com base em fundamento a respeito do qual não se tenha dado às partes oportunidade de se manifestar, ainda que se trate de matéria sobre a qual deva decidir de ofício".

77 ASSIS, Araken de. Processo civil brasileiro: parte geral: fundamentos e distribuição de conflitos. São Paulo: Revista dos Tribunais, 2015. v. 1. p. 275.

78 CPC/73: Art. 301. "Compete-lhe, porém, antes de discutir o mérito, alegar: I - inexistência ou nulidade da citação; II - incompetência absoluta; III - inépcia da petição inicial; IV - litispendência; V - coisa julgada; VI - conexão; VII - incapacidade da parte, defeito de representação ou falta de autorização; VIII - compromisso arbitral; IX - carência de ação; X - falta de caução ou de outra prestação, que a lei exige como preliminar. (...)". $\S 4^{\mathrm{o}}$ "Com exceção do compromisso arbitral, o juiz conhecerá de oficio da matéria enumerada neste artigo". O CPC 2015 manteve, com alguns ajustes, aquele entendimento: Art. 337, § 5: "Excetuadas a convenção de arbitragem e a incompetência relativa, o juiz conhecerá de ofício das matérias enumeradas neste artigo". BRASIL. Lei no 5.869, de 11 de janeiro de 1973. Institui o Código de Processo Civil. Diário Oficial da República Federativa do Brasil, Brasília, DF, 11 jan. 1973.

79 CPC/73: Art. 219, § 50: "O juiz pronunciará, de ofício, a prescrição". BRASIL. Lei no 5.869, de 11 de janeiro de 1973. Institui o Código de Processo Civil. Diário Oficial da República Federativa do Brasil, Brasília, DF, 11 jan. 1973.

80 CPC/73: Art. 267. "Extingue-se o processo, sem resolução de mérito: I - quando o juiz indeferir a petição inicial; Il - quando ficar parado durante mais de 1 (um) ano por negligência das partes; III - quando, por não promover os atos e diligências que Ihe competir, o autor abandonar a causa por mais de 30 (trinta) dias; IV - quando se verificar a ausência de pressupostos de constituição e de desenvolvimento válido e regular do processo; $\mathrm{V}$ - quando o juiz acolher a alegação de perempção, litispendência ou de coisa julgada; Vl - quando não concorrer qualquer das condições da ação, como a possibilidade jurídica, a legitimidade das partes e o interesse processual; VII - pelo compromisso arbitral; Vll - pela convenção de arbitragem;". BRASIL. Lei no 5.869, de 11 de janeiro de 1973. Institui o Código de Processo Civil. Diário Oficial da República Federativa do Brasil, Brasília, DF, 11 jan. 1973.

81 CPC/73: Art. 219, § 5: "O juiz pronunciará, de ofício, a prescrição". BRASIL. Lei no 5.869, de 11 de janeiro de 1973. Institui o Código de Processo Civil. Diário Oficial da República Federativa do Brasil, Brasília, DF, 11 jan. 1973. 
82 A previsão colidiu com a possibilidade de o titular renunciar à prescrição. $O$ art. 191 do Código Civil é expresso a respeito: "A renúncia da prescrição pode ser expressa ou tácita, e só valerá, sendo feita, sem prejuízo de terceiro, depois que a prescrição se consumar; tácita é a renúncia quando se presume de fatos do interessado, incompatíveis com a prescrição". BRASIL. Lei n ${ }^{0}$ 10.406, de 10 de janeiro de 2002. Institui o Código Civil. Diário Oficial da República Federativa do Brasil, Brasília, DF, 10 jan. 2002.

83 Relator Ministro Teori Albino Zavascki, Primeira Seção, j. em 10/6/2009, DJe 18/6/2009 e RSSTJ vol. 38 p. 448.

84 "TRIBUTÁRIO E PROCESSO CIVIL. EXECUÇÃO FISCAL. IPTU. PRESCRIÇÃO. DECLARAÇÃO DE OFÍCIO. VIABILIDADE. 1. Em execução fiscal, a prescrição ocorrida antes da propositura da ação pode ser decretada de ofício, com base no art. 219, § 5 , do CPC (redação da Lei 11.051/04), independentemente da prévia ouvidada Fazenda Pública. O regime do $\S 4^{\circ}$ do art. 40 da Lei 6.830/80, que exige essa providência prévia, somente se aplica às hipóteses de prescrição intercorrente nele indicadas. Precedentes de ambas as Turmas da $1^{\text {a }}$ Seção. 2. Recurso especial desprovido. Acórdão sujeito ao regime do art. 543-C do CPC e da Resolução STJ 08/08", Recurso Especial nº 1.100.156/RJ.

85 Nesse sentido: NERY JUNIOR, Nelson; ANDRADE, Rosa Maria de. Comentários ao código de processo civil. São Paulo: Revista dos Tribunais, 2015. p. 215-218.

86 O direito material também traz orientação para o magistrado conhecer das nulidades, mesmo sem provocação, a exemplo do disposto no parágrafo único do art. 168 do Código Civil: "As nulidades devem ser pronunciadas pelo juiz, quando conhecer do negócio jurídico ou dos seus efeitos e as encontrar provadas, não lhe sendo permitido supri-las, ainda que a requerimento das partes". BRASIL. Lei no 10.406, de 10 de janeiro de 2002. Institui o Código Civil. Diário Oficial da República Federativa do Brasil, Brasília, DF, 10 jan. 2002.

87 "A garantia fundamental da Justiça e regra essencial do processo é o princípio do contraditório, segundo este princípio, todas as partes devem ser postas em posição de expor ao juiz as suas razões antes que ele profira a decisão. As partes devem poder desenvolver suas defesas de maneira plena e sem limitações arbitrárias" (LIEBMAN apud MARCATO, Antônio Carlos. Preclusões: limitação ao contraditório? Revista de Processo, São Paulo, v. 5, n, 17, 1980).

88 Aos tribunais, entretanto, como regra, faz-se necessária a observância da "cláusula de reserva de plenário", descrita pelo art. 97 da Constituição Federal: "Somente pelo voto da maioria absoluta de seus membros ou dos membros do respectivo órgão especial poderão os tribunais declarar a inconstitucionalidade de lei ou ato normativo do Poder Público."

89 ASSIS, op. cit., p. 424.

90 O Superior Tribunal de Justiça decidiu em sede de Agravo Regimental em Recurso Especial que a omissão a respeito do efeito repristinatório não afasta a sua ocorrência. Nesse sentido: "TRIBUTÁRIO E PROCESSUAL CIVIL. CONTRIBUIÇÃO PREVIDENCIÁRIA. EMPREGADOR RURAL PESSOA FÍSICA. RECEITA BRUTA. COMERCIALIZAÇÃO DA PRODUÇÃO RURAL. DECLARAÇÃO DE INCONSTITUCIONALIDADE PELO STF. EFEITO REPRISTINATÓRIO. CONSEQUÊNCIA LÓGICOJURÍDICA. JULGAMENTO EXTRA PETITA. NÃO OCORRÊNCIA. 1. Cuida-se, na origem, Mandado de Segurança, no qual se sustenta a inconstitucionalidade da contribuição previdenciária incidente sobre a receita bruta proveniente da comercialização da produção do empregador rural pessoa física, conforme previsto no art. 25 da Lei 8.212/1991. 2. O agravante se insurge contra o reconhecimento de que, por força do efeito repristinatório da declaração de inconstitucionalidade assentada pelo Tribunal a quo, "o regime de tributação retorna ao modelo anterior ao da Lei n. 8.540/92, qual seja, o da contribuição sobre a folha de salários adicionada do SAT (artigo 22, I e II, da Lei n. 8.212/91)" (fl. 177). 3. Conforme assentado pelo STJ, em casos análogos, o reconhecimento do efeito repristinatório da legislação em vigor anteriormente é consequência lógico-jurídica da declaração de inconstitucionalidade (AgRg no REsp 1.491.806/PR, Rel. Ministro Mauro Campbell Marques, Segunda Turma, DJe 19.12.2014; AgRg no REsp 1.419.397/RS, Rel. Ministro Og Fernandes, Segunda Turma, DJe 12.11.2014). 4. Assim, não há falar em julgamento extra petita, uma vez que o reconhecimento em tese da possibilidade de o indébito ser compensado com eventual crédito constituído de contribuição previdenciária sobre a folha de salários, em razão do efeito repristinatório da declaração de inconstitucionalidade, é inerente aos limites da demanda. 5. O art. 15, parágrafo único, da Lei 8.212/1991 equipara o empregador rural pessoa física (contribuinte individual) à empresa (AgRg no REsp 1.358.091/RS, Rel. Ministro Humberto Martins, Segunda Turma, DJe 19/5/2014).6. O STF, no RE 363.852, indeferiu requerimento de modulação dos efeitos 
do julgamento, o que não se confunde com o alegado afastamento do efeito repristinatório. A propósito, colhe-se do voto condutor do Ministro Marco Aurélio afirmação que autoriza o reconhecimento da restauração da vigência da contribuição previdenciária sobre a folha de salários: "Forçoso é concluir que, nos casos do produtor rural, embora pessoa natural, que tenha empregados, incide a previsão relativa ao recolhimento sobre o valor da folha de salários".7. Agravo Regimental não provido. (AgRg no REsp 1552405/PR, 2ª Turma, Rel. Min. Herman Benjamin, j. em 24/11/2015, DJe de 04/02/2016). Disponível em: < https://ww2.stj.jus.br/processo/ revista $/$ documento $/$ mediado $/$ ?componente $=I T A \&$ sequencial $=1469571 \&$ num_registro $=201502178182 \&$ da $\mathrm{ta}=20160204 \&$ formato $=$ PDF $>$. Acesso EM: 16 nov. 2016.

\title{
THE REINSTATEMENT EFFECT ON THE DIFFUSE CONTROL OF CONSTITUTIONALITY AND THE PROHIBITION OF SURPRISE DECISIONS
}

\begin{abstract}
The unconstitutional normative act is null. When the unconstitutionality of a normative act is declared, the acts revoked by it will be automatically reinstated, since they had not been validly revoked. This is the essence of the so-called reinstatement effect, which is not to be confused, despite the semantic similarity, with reinstatement. The reinstatement effect will be applied automatically in the decision that declares the unconstitutionality of normative acts. It occurs in decisions on the control of constitutionality, in general, and it remains to be seen whether in diffuse control of constitutionality the caution of observing the principles of the adversary system should be adopted, especially by virtue of articles 9 and 10 of the current Code of Civil Procedure.

Keywords: Unconstitutional act. Nullity. Reinstatement effect. Diffuse control of constitutionality and the adversary system.
\end{abstract}

Submetido: 1 mar. 2017

Aprovado: 6 jun. 2017 